\title{
MILK WHEY AS A DILUENT FOR BUFFALO SEMEN*
}

\author{
N. G. GANGULI, M. BHOSREKAR AND \\ JOSE STEPHAN \\ National Dairy Research Institute, Karnal, Haryana 132001, India
}

(Received 11th April 1973)

\begin{abstract}
Summary. Citric acid whey was observed to be a suitable diluent for preserving buffalo semen both at room and at refrigerated temperature, as revealed by motility studies and conception rate. A 35 to $40 \%$ recovery rate was obtained with buffalo spermatozoa frozen in citric acid whey with glycerol.
\end{abstract}

The buffalo is a milch animal of considerable economic importance in some Asian countries, and efforts are being made to improve the characteristics of the breed. To hasten this process, it is of paramount importance to make full use of the best buffalo bulls and an effective method for the preservation of semen is vital if this is to be achieved. The conventional egg-yolk citrate (EYC) diluent used for bull semen (Phillips \& Lardy, 1940; Salisbury, Fuller \& Willet, 1941; Maule, 1962) is less effective for buffalo semen (Prabhu, 1956; Roy, Srivastava \& Pundey, 1956; Bhattacharya, 1962; Pavithran, Vasanth, Bhima Sena Rao \& Anantakrishnan, 1972), the buffalo spermatozoa survived for a shorter time than bull spermatozoa (Gokhale, 1958; Rao, 1958; Bhattacharya, 1962). Compositional differences between bull and buffalo semen were also reported earlier (Banerjee \& Ganguli, 1971, 1973). The present communication reports the results of experiments on the use of milk and its fraction (mainly whey) on the motility and fertility rates of buffalo spermatozoa. Some preliminary results on this aspect were reported earlier (Bhosrekar, Ganguli \& Stephen, 1972; Ganguli, Bhosrekar \& Stephen, 1973).

Ejaculated semen was collected from ten buffalo (Murrah) bulls with an artificial vagina (Herman \& Madden, 1953). Those samples with a mass activity of 3 to 4 or greater (motility scale, Herman \& Madden, 1953) were pooled, and $0.5 \mathrm{ml}$ of the pooled semen was diluted slowly with $4 \mathrm{ml}$ of diluent. Half of each mixture was stored at $30^{\circ} \mathrm{C}$ and the other half at $5^{\circ}$ to $7^{\circ} \mathrm{C}$ for $1 \mathrm{hr}$.

The following diluents were used (all contained $1000 \mathrm{i}$.u. sodium pencillin $\mathrm{G} / \mathrm{ml}+3 \mathrm{mg}$ streptomycin sulphate/ml): (i) Egg yolk citrate (EYC); (ii) Soda bicarb-glucose-fructose egg yolk (SGFE) (Tomar, Pande \& Desai, 1964); [These two served as controls for the preparations made from skim milk of buffalo, cow and goat, the skim milk was prepared in an Alfa-Laval cream separator and all milk preparations were heated to $92^{\circ} \mathrm{C}$ for $10 \mathrm{~min}$ before use];

* N.D.R.I. Publications No. 73-10. 
(iii) Skim milk, (iv) Skim milk egg yolk (SMEY) (Tomar \& Desai, 1961); (v) Ultracentrifugal whey (UCW) obtained by centrifuging skim milk at 105,000 $\mathrm{g}$ for $30 \mathrm{~min}$; (vi) UCW $+7 \%$ glycerol (UCWG); (vii) Micellar casein, the residue after the removal of UCW; (viii) Citric acid whey (CAW) obtained by curdling skim milk with citric acid at pH 4.5 ; the casein was filtered off through a cotton plug and the $\mathrm{pH}$ of CAW was adjusted to 6.8 with $10 \% \mathrm{NaOH}$; (ix) $\mathrm{CAW}+7 \%$ glycerol $(\mathrm{CAWG})$; (x) As for CAW, but using $\mathrm{HCl}$ instead of

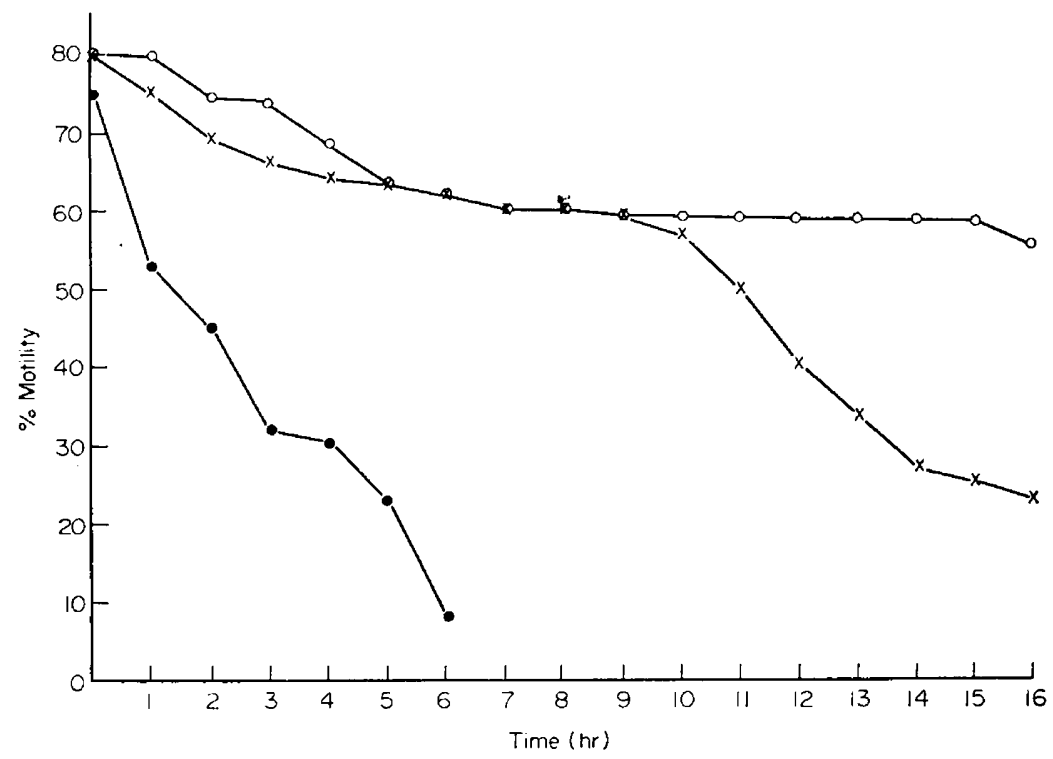

TExT-FIG. 1. Motility rate of buffalo spermatozoa in different diluents: $\bullet$, EYG; 0 , CAW; $x$, HCl-whey. For abbreviations, see text.

citric acid; (xi) As for CAW, but with acetic acid; (xii) CAW from colostrum; (xiii) CAW with fructose; (xiv) CAW with lactose; (xv) Fraction of skim milk retained by dialysis membrane (dialysed skim milk); (xvi) Fraction of skim milk which passed through a dialysis membrane.

The dialysis fluid was citrate buffer.

In addition to being held at $30^{\circ} \mathrm{C}$ and $5^{\circ} \mathrm{C}$, semen diluted in glycerol was deep frozen over liquid nitrogen (Settergren, 1966).

The efficacy of the diluents was tested by examining the motility of spermatoza at $37^{\circ} \mathrm{G}$ under the microscope (at 200 times magnification) after dilution and subsequently every hour. Limited fertility trials with semen extended with CAW were also conducted by artificial insemination (Herman \& Madden, 1953). A single observer estimated the sperm motility in a single sample from each diluent every hour for $8 \mathrm{hr}$ and then every $24 \mathrm{hr}$. For room temperature studies, motility was recorded every hour up to $18 \mathrm{hr}$. The experiment was repeated eight times.

Milk preparations from buffalo and goat did not preserve sperm motility as well as did cow's milk preparations. Micellar casein, dialysed skim milk and CAW from colostrum were all ineffective. 
At $30^{\circ} \mathrm{C}$, more than $50 \%$ of the spermatozoa were motile after $16 \mathrm{hr}$ in CAW. The addition of lactose or fructose did not affect this. Citric acid whey was superior to $\mathrm{HCl}$ whey which was better than EYC (Text-fig. 1). Acetic acid whey was not effective.

Table 1. Motility of buffalo spermatozoa in different diluents at $4^{\circ} \mathrm{C}$

\begin{tabular}{|c|c|c|c|}
\hline \multirow{2}{*}{ Diluent used } & \multicolumn{3}{|c|}{$\%$ motility } \\
\hline & $0 \mathrm{hr}$ & $96 \mathrm{hr}$ & $144 h r$ \\
\hline $\begin{array}{l}\text { Skim milk } \dagger \\
\text { Skim milk egg-yolk } \\
\text { Gitric acid whey } \\
\text { GAW + glycerol (7\%) } \\
\text { Ultracentrifugal whey (UCW) } \\
\text { UGW + glycerol ( } 7 \% \text { ) } \\
\text { Egg-yolk-citrate } \\
\text { Soda bicarb- } \\
\text { glucose-fructose-egg yolk }\end{array}$ & $\begin{array}{l}98 \cdot 0 \pm 0 \cdot 80 \\
80 \cdot 0 \pm 0 \cdot 82 \\
73 \cdot 0 \pm 2 \cdot 11 \\
82 \cdot 0 \pm 15 \cdot 55 \\
80 \cdot 0 \pm 0 \cdot 0 \\
83 \cdot 0 \pm 1 \cdot 11 \\
76 \cdot 0 \pm 1 \cdot 83 \\
77 \cdot 0 \pm 1 \cdot 64\end{array}$ & $\begin{array}{l}60 \cdot 0 \pm 1 \cdot 82 \\
52 \cdot 0 \pm 4 \cdot 90 \\
62 \cdot 0 \pm 17 \cdot 11 \\
44 \cdot 0 \pm 2 \cdot 45 \\
62 \cdot 0 \pm 3 \cdot 07 \\
15 \cdot 0 \pm 1 \cdot 83 \\
17 \cdot 0 \pm 3 \cdot 34\end{array}$ & $\begin{array}{c}\text { 二 } \\
30.0 \pm 14.20 \\
50.0 \pm 3.07 \\
\text { 52.0土3.74 } \\
=\end{array}$ \\
\hline
\end{tabular}

* The data are expressed as mean \pm standard error.

$\dagger$ Skim milk and whey were preparations from cow's milk only. In all cases, at least eight experiments were carried out.

The results obtained with cow's milk preparations at $5^{\circ}$ to $7^{\circ} \mathrm{C}$ are presented in Table 1. As a result of the prolonged survival obtained with CAW, 297 inseminations were performed using spermatozoa in CAW after storage at $5^{\circ}$ to $7^{\circ} \mathrm{C}$ for up to $72 \mathrm{hr}$. A conception rate of $50 \%$ was achieved. Citric acid whey was preferred to UCW because it was easier to prepare. A 35 to $40 \%$ recovery rate was obtained with buffalo spermatozoa frozen in CAWG in polyvinyl straws.

We are indebted to Dr D. Sundaresan, Director, National Dairy Research Institute, Karnal for his continued encouragement in this project. Our thanks are also due to $\mathrm{Mr} \mathrm{O}$. P. Tandon, for the routine help in this work.

\section{REFERENCES}

Banerjee, A. K. \& Ganguli, N. C. (1971) Differentiation of semen from Bos bubalus and Bos taurus indicus by starch gel electrophoresis. F. Anim. Sci. 32, 1212.

Banerjee, A. K. \& Ganguli, N. C. (1973) Some aspects of the composition of buffalo semen. 7. Reprod. Fert. 33, 171.

Bhattacharya, P. (1962) Cited in Maule, J. P. (1962).

Bhosrekar, M., Ganguli, N. C. \& Stephen, J. (1972) Keeping quality of buffalo semen in milk and milk fractions. 9th Dairy Industry Conference, Gauhati, India.

Ganguli, N. C., Bhoskekar, M. \& Stephen, J. (1973) Milk whey: a new extender for buffalo semen. VIII Int. Symp. Zootechny, Milan.

Gokitale, D. R. (1958) Glucose sodium bicarbonate and sulpliamezathine buffer as a diluent for buffalo semen. Indian vet. F. 35, 573 .

Herman, H. A. \& Madden, F. W. (1953) The artificial insemination of dairy cattle. A handbook and laboratory mantal. Lucas Brothers, Columbia, U.S.A.

Maule, J. P. (1962) The semen of animals and artificial insemination. Commonw. Agric. Bureaux, England.

Pavithran, K., Vasanth, J. K., Bhima Sena Rao, M. \& Anantakrishnan, C. P. (1972) A method for deep freezing of buffalo semen. Indian vet. 7. 49, 1125.

Puillips, P. H. \& LaRdy, H. A. (1940) A yolk-buffer pabulum for the preservation of bull semen. J. Dairy Sci. 23, 399. 
PRABHU, S. S. (1956) Influence of factors affecting sex drive on semen production of buffaloes. II. Indian F. vet. Sci. 26, 21.

Rao, C. K. (1958) Development of motility in spermatozoa of farm animals. Indian vet. 7. 35, 97.

Roy, A., Srivastava, R. K. \& Pundey, M. D. (1956) Deep freezing of buffalo semen diluted and preserved in glycine-egg yolk medium. Indian F. Dairy Sci. 9, 61.

Salisbury, G. W., Fuller, H. K. \& Willes, E. L. (1941) Preservation of bovine spermatozoa in yolk citrate diluent and field results from its use. F. Dairy Sci. 24, 905.

Settergren, I. (1966) Report to Government of India on deep freezing techniques for preservation of semen to be used in Artificial Insemination. Report No. 2127.

Tomar, N. S. \& Desai, R. N. (1961) A comparative study of various dilutors for preservation of buffalo semen at 5 to $7^{\circ}$ C. II. Skim milk containing dilutors. Indian $\mathcal{F}$. Dairy Sci. 14, 61 .

Tomar, N. S., PANDE, R. \& Desai, R. N. (1964) Efficacy of semen diluents to preserve the normal morphology of bovine spermatozoa. Indian J. Dairy Sci. 17, 104. 